\title{
Downscaling future climate scenarios to fine scales for hydrologic and ecological modeling and analysis
}

\author{
Lorraine E Flint ${ }^{*}$ and Alan L Flint
}

\begin{abstract}
Introduction: Evaluating the environmental impacts of climate change on water resources and biological components of the landscape is an integral part of hydrologic and ecological investigations, and the resultant land and resource management in the twenty-first century. Impacts of both climate and simulated hydrologic parameters on ecological processes are relevant at scales that reflect the heterogeneity and complexity of landscapes. At present, simulations of climate change available from global climate models [GCMs] require downscaling for hydrologic or ecological applications.

Methods: Using statistically downscaled future climate projections developed using constructed analogues, a methodology was developed to further downscale the projections spatially using a gradient-inverse-distancesquared approach for application to hydrologic modeling at 270-m spatial resolution.

Results: This paper illustrates a methodology to downscale and bias-correct national GCMs to subkilometer scales that are applicable to fine-scale environmental processes. Four scenarios were chosen to bracket the range of future emissions put forth by the Intergovernmental Panel on Climate Change. Fine-scale applications of downscaled datasets of ecological and hydrologic correlations to variation in climate are illustrated.

Conclusions: The methodology, which includes a sequence of rigorous analyses and calculations, is intended to reduce the addition of uncertainty to the climate data as a result of the downscaling while providing the fine-scale climate information necessary for ecological analyses. It results in new but consistent data sets for the US at $4 \mathrm{~km}$, the southwest US at $270 \mathrm{~m}$, and California at $90 \mathrm{~m}$ and illustrates the utility of fine-scale downscaling to analyses of ecological processes influenced by topographic complexity.
\end{abstract}

Keywords: downscaling, climate change, spatial scale, scenarios

\section{Background and introduction}

Climate change has become an integral part of conducting hydrologic and ecological studies in the twenty-first century. In general, the best scientific evidence suggests that global warming has been occurring and will continue to occur during this century no matter what management approaches to ameliorate climate change are implemented (California Department of Water Resources 2008). Were we to eliminate all anthropogenic greenhouse gas emissions today, about half of the anthropogenic $\mathrm{CO}_{2}$ would be removed from the atmosphere within 30 years, but the remaining atmospheric

\footnotetext{
* Correspondence: Iflint@usgs.gov

U.S. Geological Survey, Placer Hall, 6000 J St., Sacramento, CA 95819, USA
}

$\mathrm{CO}_{2}$ would remain for centuries (IPCC 2007). To assess the impacts of climate change, many global socio-economic scenarios are being developed by the Intergovernmental Panel on Climate Change [IPCC] to provide climate scenarios that take into account estimates of possible magnitudes of greenhouse gas emissions that are responsible for much of the climate change. These scenarios are used as boundary conditions for global climate models [GCMs] that provide us with insight into how human behavior in the future may influence changes in climate. These GCMs lack orographic detail, having a coarse spatial resolution with a grid-cell size on the order of $2.5^{\circ} \times 2.5^{\circ}$ (approximately $275 \times 275$ $\mathrm{km}^{2}$ ), which is far too coarse for landscape or basin- 
scale models that investigate hydrologic or ecological implications of climate change. The meso-scale (1 to $100 \mathrm{~km}$ ) climate surfaces provided by most GCM outputs are also too coarse to provide correlations of ecological processes and vegetation distribution needed for understanding threats to biodiversity, and for conservation planning.

Physical and hydrologic processes such as springtime snowmelt, aquifer recharge, forest die-off, or vegetation distributions occur at a myriad of spatial scales. Oak woodlands may be dominant on north-facing slopes in one basin, while another has no aspect bias. Snow melting in the high-elevation Sierra Nevada Mountains under warming climatic conditions may be delayed by weeks in some subbasins in comparison to others (Lundquist and Flint 2006), providing uncertainty for biological and water-resource processes. Conditions driving the processes may be far more relevant at the hillslope scale for some investigations, such as rare plant species distribution, runoff and overland flow as ungauged streamflow distributions of evapotranspiration for agricultural and native vegetation, etc.; the subbasin scale may be appropriate for springtime runoff for fisheries, and the regional scale may be the necessary tool to evaluate water resources in the southwest. The majority of climate change studies are using readily available climate projections at scales greater than $1 \mathrm{~km}$.

The need for fine-scale investigations of ecological processes for species distribution models is related to the differences in model results between meso-scale (coarse) and topo-scale (fine; 0.01 to $1 \mathrm{~km}$ ) environments, whereby fine-scale models that capture fine-scale environments show markedly different range loss and extinction estimates than coarse-scale models for some species. Results from the western US suggest that fine-scale models may predict vegetation to persist where coarse-scale models show no suitable future climate (Guisan and Thuiller 2005; Dobrowski 2010). Fine-scale spatial heterogeneity should provide greater opportunity for migration and reassembly of communities (Ackerly et al. 2010). This is related to the topographic variation in climate at the topo-scale environment that can exert strong influences on establishment patterns (Callaway and Davis 1998; Keyes et al. 2009). At a finer scale (well below the spatial resolution available in commonly used gridded climate products such as the Parameter-elevation Regressions on Independent Slopes Model [PRISM] at $4 \mathrm{~km}$ and $800 \mathrm{~m}$, and WorldClim at $1 \mathrm{~km}$ ), topoclimate diversity may provide significant spatial buffering that will modulate the local impacts of climate change. Several researchers are currently linking simple fine-scale (25 to $50 \mathrm{~m}$ ) climatologies to correlational species distribution models (Randin et al. 2009; Trivedi et al. 2008).
Climatic data are normally available at a spatial scale of 1,000 to $10,000 \mathrm{~km}^{2}$, while plant growth is normally measured at a much smaller scale of $100 \mathrm{~m}^{2}$ to $10 \mathrm{~km}^{2}$. Thus, a plant may actually 'experience' a local climate that is quite different from the larger scale climatic data used to quantify climate-growth relationships (Peterson et al. 1998). The scale of topoclimates $(0.5 \mathrm{~km}$ to $10 \mathrm{~m})$ is the spatial scale at which topography can be used to describe the climate near the ground (Geiger et al. 2003), thus more closely approximating the experience of the organism. The discrete influence of complex environments on habitats and species incorporates topographic shading that influences solar radiation and evapotranspiration, frost pockets or cold-air pooling, and differences in soils, all of which can be described on the basis of topoclimates.

A suite of investigations has detected the improvement in developing species-environment associations using information to account for topographic complexity. Lookingbill and Urban $(2003,2005)$ determined that spatial variations in temperature have a large influence on the distribution of vegetation and are therefore, a vital component of species distribution models (Ashcroft et al. 2008). Topographic variability of a steep alpine terrain creates a multitude of fine-scale thermal habitats that is mirrored in plant species distribution, warning against projections of the responses of alpine plant species to climate warming that adopt a broad-scale isotherm approach (Scherrer and Korner 2010). Topographic complexity and the associated fine-scale heterogeneity of climate dictate the velocity with which current temperature isoclimates are projected to move under climate change scenarios, and this spatial heterogeneity in climate represents an important spatial buffer in response to climate change (Loarie et al. 2009; Ackerly et al. 2010). Wiens (1989) notes that choice of spatial scale is critical in analyzing species-environment associations, and Guisan and Thuiller (2005) describe it as a central problem in bioclimate modeling. The $1-\mathrm{km}$ (or greater) scale was shown to be less effective for species distribution modeling when multiple biophysical attributes, climate, geology, and soils were being used for correlation analyses in a study of forest composition and sudden oak death in the Big Sur region (Davis et al. 2010). In this study, it was determined that the 90-m resolution climate data proved especially important in resolving the strongly contrasting and locally inverted temperature regimes associated with the marine boundary layer near the coast and for approximating the sampling scale of the field sites. A similar conclusion was reached in a California-wide study of valley oak genetic adaptation to rapid climate change, where 90-m climate data provided excellent correlations with the geographic 
patterns of multivariate genetic variation associated with climatic conditions (Sork et al. 2010).

An example of increases in variability with decreases in scale is illustrated in Ackerly et al. (2010). In this example, the PRISM mesoclimate gradient exhibits a range of just $3^{\circ} \mathrm{C}$ in January minimum temperatures on the landscape of the San Francisco Peninsula. However, topoclimatic effects modeled at a $30-\mathrm{m}$ scale add a local variability of $8^{\circ} \mathrm{C}$ nested within the mesoclimate. They conclude that the effects of topoclimatic gradients on the distribution and abundance of organisms can be profound in the Bay Area grasslands, where fine-scale topography provides resilience in the face of year-toyear climate variation, influencing the emergence time of Bay Checkerspot butterflies in relation to the phenology of its host plants (Weiss and Weiss 1998; Hellman et al. 2004). Although downscaling at a regional level to $30 \mathrm{~m}$ can be prohibitive due to large file sizes and model runtimes, a fine scale of $270 \mathrm{~m}$ captures the topographic variability and corresponding ranges in air temperature, providing for information and enhanced interpretation for conservation planning.

Downscaling is the process of transferring the climate information from a climate model with coarse spatial and fine temporal scales to the fine scale required by models that address effects of climate. Although dynamical downscaling can be achieved using a regional climate model, it is computationally expensive and currently is not practical for processing multi-decadal and/or multimodel simulations from GCMs. A viable alternative that is adequate for many applications is to use statistical downscaling, which has the advantage of requiring considerably less computational resources. In addition, GCM outputs are biased (warmer, colder, wetter, or drier than current conditions) and need to be corrected (transformed) to properly represent modern climate. To convert the results of these coarse scale and biased GCM outputs for input into local scale models, there needs to be a reasonable and systematic process of downscaling and bias correction to produce new data sets that correctly represent the implications of the GCMs but at a scale applicable to local studies. In this paper, we provide an additional example to illustrate the relevance of fine-scale applications at the 270-m scale.

This paper provides a novel approach to address the complex impacts of climate change on the landscape as a result of changes in precipitation and air temperature and the resultant hydrologic response. The approach combines downscaling of global climate projections at $2^{\circ}$ spatial resolution to a fine scale of 270-m spatial resolution, verified for accuracy with measured data, and applies the results to a hydrologic model to illustrate the potential application for analyses of impacts of climate change to ecological processes at the landscape, basin, and hillslope scales.

This discussion describes the method used to downscale and bias-correct national monthly GCM outputs and provides new internally consistent data sets for hydrologic and ecological-scale modeling for the US at 4 $\mathrm{km}$, the southwest including California at $270 \mathrm{~m}$, and California at $90 \mathrm{~m}$. These datasets are currently being used in multiple state and region-wide investigations at $270 \mathrm{~m}$ and $90 \mathrm{~m}$, and the procedure descriptions will address the 270-m fine-scale resolution. For illustrative purposes, fine-scale applications of these downscaled datasets of ecological and hydrologic correlations to variation in climate are provided using a relatively dry model with business-as-usual emissions.

\section{Methods: downscaling approach and application Climate change scenarios}

On the basis of analyses done by Cayan et al. (2008), climate change scenarios were selected from those used in the IPCC Fourth Assessment. Two emission scenarios were selected to range from optimistic to business-asusual. Two models were required to contain realistic representations of some regional features, such as the spatial structure of precipitation and important orographic features, and to produce a realistic simulation of aspects of California's recent historical climate - particularly the distribution of monthly temperatures and the strong seasonal cycle of precipitation that exists in the region and throughout the western states. Because the observed western US climate has exhibited considerable natural variability at seasonal to interdecadal time scales, the historical simulations by the climate models were required to contain spatial and temporal variability that resembles that from observations at shorter time scales. Finally, the selection of models was designed to include models with differing levels of sensitivity to greenhouse gas forcing. On the basis of these criteria, two GCMs were identified: the parallel climate model [PCM] (with simulations from NCAR and DOE groups; see Washington et al. 2000; Meehl et al. 2003) and the NOAA geophysical fluid dynamics laboratory [GFDL] CM2.1 model (Stouffer et al. 2006; Delworth et al. 2006). The choice of greenhouse gas emission scenarios which focused on A2 (medium-high) and B1 (low) emissions was based upon implementation decisions made earlier by IPCC (Nakic'enovic' et al. 2000).

The $\mathrm{B} 1$ scenario assumes that global $\mathrm{CO}_{2}$ emissions peak at approximately 10 gigatons per year [Gt/year] in the mid-twenty-first century before dropping below current levels by 2100 . This yields a doubling of $\mathrm{CO}_{2}$ concentrations relative to its pre-industrial level by the end of the century (approximately $550 \mathrm{ppm}$ ), followed by a 
leveling of the concentrations. Under the A2 scenario, $\mathrm{CO}_{2}$ emissions continue to climb throughout the century, reaching almost $30 \mathrm{Gt} /$ year.

\section{Statistical downscaling}

The two general approaches for interpolating GCM outputs are statistical and dynamical downscaling. In dynamical downscaling, the GCM outputs are used as boundary conditions for finer-resolution regional-scale GCM models. This technique is computer intensive, requires detailed, finer-scale full physical weather and ocean models, and will not be used here. Statistical downscaling methods apply statistical relations between historical climate records at coarse resolutions and fine resolutions to interpolate from coarse model outputs to finer resolutions. This requires much less computational effort but generally involves extreme simplifications of the physical relations. One recent example is a deterministic, linear approach that relies on the spatial patterns of historical climate data called constructed analogues. By linear regressions with the current weather or climate pattern as the dependent variable and selected historical patterns as independent variables, high-quality analogues can be constructed that tend to describe the evolution of weather or climate into the future for a time (Hidalgo et al. 2008). The approach implicitly assumes stationarity in time and space (Milly et al. 2008) and was inspired by an approach for predicting climatic patterns by van den Dool et al. (2003).

The statistical downscaling method of constructed analogues was developed at Scripps Institution of Oceanography by Hidalgo et al. (2008) and used here for these four scenarios. Models selected for downscaling have been downscaled from coarse-resolution GCM daily and monthly maps (approximately $275 \mathrm{~km}$ ) to $12-\mathrm{km}$ national maps (binary files can be found at http://tenaya.ucsd.edu/wawona-m/downscaled/). This method uses continental-scale historical (observed) patterns of daily precipitation and air temperature at coarse resolution and their fine-resolution (approximately $12 \mathrm{~km}$ ) equivalents with a statistical approach to climate prediction based on the conceptual framework of van den Dool et al. (2003). This method assumes that if one could find an exact analogue (in the historical record) to the weather field today, weather in the future should replicate the weather following the time of that exact analogue. This approach is analogous to the principal component analysis with multiple dependent variables that represents various similar historical snapshots. Procedurally, a collection of historically observed coarseresolution climate patterns is linearly regressed to form a best-fit constructed analogue of a particular coarseresolution climate-model output. The constructed analogue method develops a downscaled, finer-resolution climate pattern associated with the climate-model output from the (same) linear combination of historical fine-resolution patterns as was fitted to form the coarseresolution analogue. Thus, the regression coefficients that form the best-fit combination of coarse-resolution daily maps (at $275-\mathrm{km}$ resolution) to reproduce a given climate-model daily pattern are applied to the fine-resolution (12-km resolution) maps from the same (historical) days.

The downscaling method of constructed analogues illustrates a high level of skill, capturing an average of $50 \%$ of daily high-resolution precipitation variance and an average of around $67 \%$ of average air temperature variance, across all seasons and across the contiguous United States. The downscaled precipitation variations capture as much as $62 \%$ of observed variance in the coastal regions during the winter months. When the downscaled daily estimations are accumulated into monthly means, an average $55 \%$ of the variance of monthly precipitation anomalies and more than $80 \%$ of the variance of average air temperature monthly anomalies are captured (Hidalgo et al. 2008).

\section{Spatial downscaling and bias correction}

Spatial downscaling here refers to the calculation of fine-scale information on the basis of coarse-scale information using various methods of spatial interpolation. This downscaling is required for the application of statistically downscaled climate parameters from the $12-\mathrm{km}$ resolution to grid resolutions that more adequately address the patchiness of ecological and environmental processes of interest. Bias correction is a necessary component in developing useful GCM projections. Without this correction applied to GCM data, which then is used in local hydrologic or ecological models, the results could be erroneous, resulting in the over or under estimation of the climatic variables. Bias correction requires a historically measured dataset for correction that is at the same grid scale as the spatially downscaled parameter set. Therefore, the initial spatial downscaling was done to $4 \mathrm{~km}$, which is the resolution of an existing historical climate dataset that is spatially distributed and grid-based. The PRISM dataset developed by (Daly et al. 1994) is a knowledge-based analytical model that integrates point data of measured precipitation and air temperature with a digital elevation model reflecting expert knowledge of complex climatic extremes, such as rain shadows, temperature inversions, and coastal effects, to produce digital grids of monthly precipitation and minimum and maximum air temperatures. Historical climatology is available from PRISM as monthly maps (http:// www.prism.oregonstate.edu/). The spatial downscaling is done using the 4-km resolution digital elevation model in PRISM prior to bias correction. 
Spatial downscaling is performed on the coarse-resolution grids $(12 \mathrm{~km})$ to produce finer-resolution grids $(4 \mathrm{~km})$ using a model developed by Nalder and Wein (1998) modified with a nugget effect specified as the length of the coarseresolution grid. Their model was developed to interpolate very sparsely located climate data over regional domains and combines a spatial gradient and inverse distance squared [GIDS] weighting to monthly point data with multiple regressions. Parameter weighting is based on location and elevation of the new fine-resolution grid relative to existing coarse-resolution grid cells using the following the equation:

$$
Z=\left[\sum_{i=1}^{N} \frac{Z_{i}+\left(X-X_{i}\right) \times C_{x}+\left(Y-Y_{i}\right) \times C_{y}+\left(E-E_{i}\right) \times C_{e}}{d_{i}^{2}}\right] /\left[\sum_{i=1}^{N} \frac{1}{d_{i}^{2}}\right](1)
$$

where $Z$ is the estimated climatic variable at a specific location defined by easting $(X)$ and northing $(Y)$ coordinates and elevation $(E) ; Z_{i}$ is the climate variable from the $12-\mathrm{km}$ grid cell $i ; X_{i}, Y_{i}$, and $E_{i}$ are easting and northing coordinates and elevation of the $12-\mathrm{km}$ grid cell $i$, respectively; $N$ is the number of $12-\mathrm{km}$ grid cells in a specified search radius; $C_{x}, C_{y}$, and $C_{e}$ are regression coefficients for easting, northing, and elevation, respectively; $d_{i}$ is the distance from the $4-\mathrm{km}$ site to $12-\mathrm{km}$ grid cell $i$ and is specified to be equal to or greater than $12 \mathrm{~km}$ (the nugget) so that the regional trend of the climatic variable with northing, easting, and elevation within the search radius does not cause the estimate to interpolate between the closest $12-\mathrm{km}$ grid cells, which causes a bull's-eye effect around any 4-km fine-resolution grid cell that is closely associated or colocated in space with an original $12-\mathrm{km}$ grid cell. For example, in the case of the $12-\mathrm{km}$ to $4-\mathrm{km}$ downscaling step, a search radius of $27 \mathrm{~km}$ is used to limit the influence of distant data but allow for approximately twentyone $12-\mathrm{km}$ grid cells to estimate the model parameters for temperature and precipitation for each $4-\mathrm{km}$ grid cell with the closest cell having the most influence. This interpolation scheme incorporates the topographic and elevational effects on the climate.

Statistical downscaling approaches use both the spatially downscaled grids and measured data for the same period to adjust the 4-km grids so that certain statistical properties, in this case the mean and standard deviation, are the same as the measured data set. To make the correction possible, the GCM is run under the historical forcings to establish a baseline for modeling to match the current climate. Baseline for this study is based on the PCM and GFDL model runs for 1950 to 2000, where the climate change forcings are absent from the model, and uses recent (pre-2000) atmospheric greenhouse gas conditions. The baseline period can be any time period but should encompass the variation imposed by the major climate cycles, such as the Pacific decadal oscillation (approximately 25 to 30 years; Gurdak et al. 2009), as these are still present in the hindcast GCM, as analyzed by Hanson and Dettinger (2005). This baseline period is corrected (transformed) using the PRISM data from the same time period.

There are different statistical downscaling methods that can be used to ensure that GCM and historical data have similar statistical properties. One commonly used method is the bias correction and spatial downscaling [BCSD] approach of Wood et al. (2004) that uses a quantile-based mapping of the probability density functions for the monthly GCM climate onto those of gridded observed data, spatially aggregated to the GCM scale. This same mapping is then applied to future GCM projections, allowing the mean and variability of a GCM to evolve in accordance with the GCM simulation, while matching all statistical moments between the GCM and observations for the base period. Recently, one hundred twelve 150-year GCM projections were downscaled over much of North America using the BCSD method (Maurer and Hidalgo 2008).

We use a method described by Bouwer et al. (2004) that uses a simple adjustment of the projected data to match the baseline mean and standard deviation. This correction is done on a cell-by-cell basis so that the correction is not global but embedded in the spatial interpolation for each location for just that month. Using the standard deviation in the formulation, the bias correction allows the GCM to be transformed to match the mean and the variability of the climate parameter to the baseline period. The equation for both temperature and precipitation is

$$
\left.C_{\text {unbiased }}=\left(\left(C_{\text {biased }}-C_{\text {amGCM }}\right) / \sigma_{\text {amGCM }}\right) \times \sigma_{\text {amPRISM }}\right)+C_{\text {amPRISM }}(2)
$$

where $C_{\text {unbiased }}$ is the bias-corrected monthly climate parameter (temperature or precipitation), $C_{\text {biased }}$ is the monthly downscaled but biased future climate parameter, $C_{\text {amGCM }}$ is the average monthly climate parameter downscaled but biased for the baseline period, $\sigma_{\text {amGCM }}$ is the standard deviation of the monthly climate parameter for the baseline period, $\sigma_{\text {amPRISM }}$ is the standard deviation for the climate parameter from PRISM for the baseline period, and $C_{\text {amPRISM }}$ is the average monthly PRISM climate parameter for the baseline period. This method was applied for this study incorporating both mean and standard deviation on a cell-by-cell data at 4- $\mathrm{km}$ resolution for the baseline time period for each month.

\section{Processing sequence}

The 12-km resolution data has been obtained from Scripps for 1950 to 2000, representing current climate, and 2000 to 2100 representing future climate for the 
three scenarios and two models. The sequence of steps for processing the data is as follows: (1) The monthly $12-\mathrm{km}$ data are spatially downscaled using GIDS to a 4-km grid designed to match grids from the PRISM digital elevation model. (2) The monthly $4-\mathrm{km}$ data for 1950 to 2000 are used to develop the bias correction statistics (mean and standard deviation) using measured or simulated current climate data for 1950 to 2000 from PRISM and from each of the two GCM models. (3) These corrections are then applied to the 2000 to 2100 monthly data. (4) Monthly data are further downscaled using GIDS to a 270-m scale for the southwest Basin Characterization Model [BCM] (a regional water-balance model; Flint and Flint 2007), including California. The processing sequence, including the step involving the downscaling of the GCM grids to the $12-\mathrm{km}$ grids using constructed analogues, is presented in Figure 1.
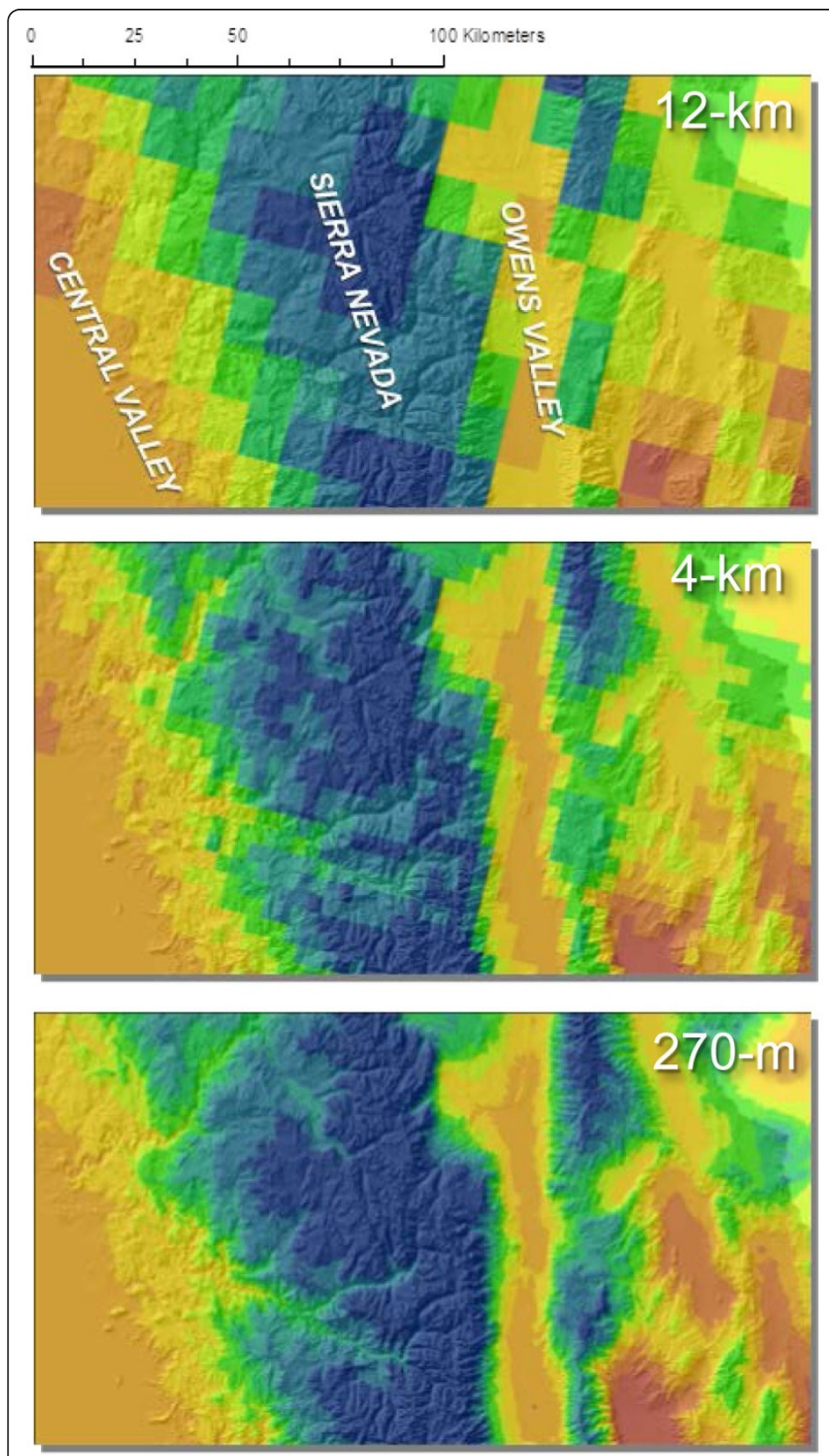

Air

\section{Temperature}

(C)

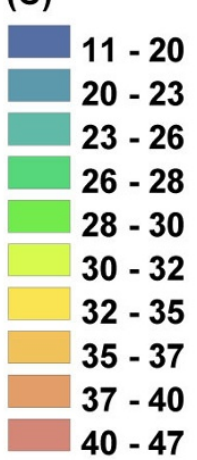

Figure 1 Spatial downscaling. Spatial downscaling using a modified gradient-inverse-distance squared method from the 12-km resolution available from Hidalgo et al. (2008) to the 270-m ecological-scale resolution, maximum monthly air temperature June 2035 using the GFDL A2 scenario. 


\section{Comparison of downscaled climate parameters and measured climate data}

An analysis was done to assess whether the spatial downscaling process introduced additional uncertainty into the final estimates of the climatic parameters. Measured monthly precipitation and maximum and minimum air temperatures from meteorological stations throughout California operated by the California Irrigation Management Information System [CIMIS] and National Weather Service [NWS] were compared to the 4-km PRISM grid cell occupied by each station (Figure 2). The station data were also compared to the 4- $\mathrm{km}$ data that was downscaled to $270 \mathrm{~m}$ to determine which of those scales was closer to the measured data. Figure 2 illustrates the physical conditions that are represented by each grid resolution in comparison with the location of the Hopland FS CIMIS station in the northern part of the Russian River basin in Sonoma County. This station is located at a 354-m elevation, while the average elevation of the 4-km grid cell is $608 \mathrm{~m}$ (Figure 2a). The 270-m cell in which the station is located is $366 \mathrm{~m}$, much closer to the station location. As a result, the representation of the data by the downscaling, which specifically takes into account the elevation of each cell, can more accurately reflect the measured data. While this example explains how the downscaling can improve the gridded estimates by incorporating the determinism that location and elevation may lend to the estimate of climate parameters, this may not always be the case, depending on whether the PRISM estimate closely matches the measured data and whether the topography is flat or very spatially variable.

\section{Application of future climate grids to a hydrologic model and characterization of topoclimates}

Downscaled monthly climate parameters, precipitation, and maximum and minimum air temperatures were applied to a regional hydrologic model (BCM; Flint and Flint 2007; Flint et al. 2004). This model relies on the calculation of hourly potential evapotranspiration [PET] determined from solar radiation that is simulated using topographic shading to calculate the water balance for every grid cell. Resulting estimates of actual evapotranspiration $[\mathrm{AET}]$ based on changes in soil moisture with changes in climate from projections can be used to calculate climatic water deficit [CWD].

CWD is the annual evaporative demand that exceeds available water and has been found to be a driver for ecological change (Stephenson 1998) and is correlated to distributions of vegetation. This correlation can be used to investigate potential changes in distribution with changes in climate. It is calculated as PET minus AET. In the BCM, AET is calculated on the basis of soil moisture content that diminishes over the dry season; therefore, in Mediterranean climates with minimal
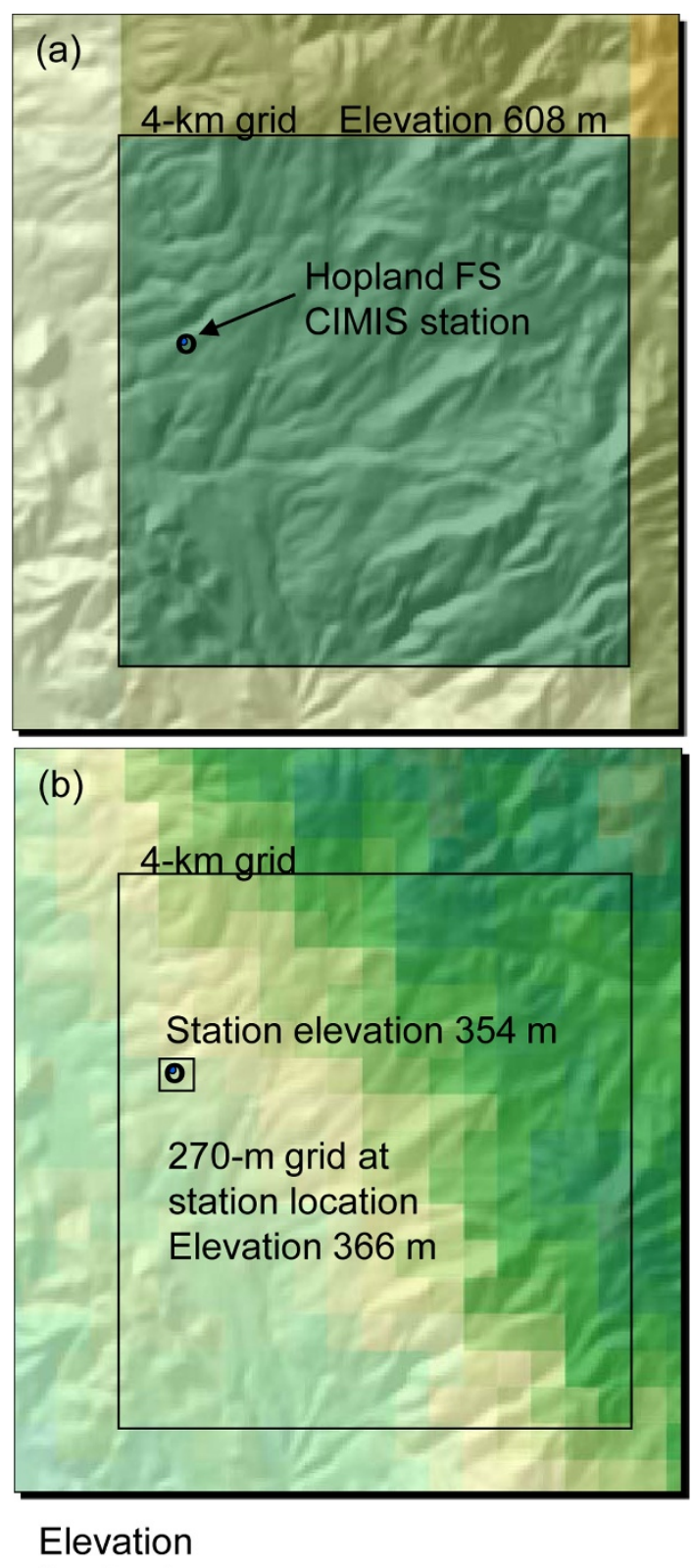

(meters)

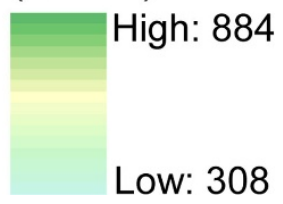

Figure 2 Close-up example of the HOPLAND FS station location The location is within the (a) PRISM 4-km grid cell and the (b) 270-m downscaled grid cell, illustrating their corresponding elevations.

summer precipitation, PET exceeds AET, thus accumulating the annual deficit.

The topoclimate is described in the BCM in the solar radiation model and resulting calculation of PET, whereby hillslopes with lower energy loads (lower 
potential evapotranspiration) are likely to have less of an impact on the basis of rising air temperatures from climate change. The fine-scale discretization of soil properties allows for the distinction of soils on the landscape with varying soil water holding capacities. Deep soils such as those in valley bottoms can extend the amount of water available for AET further into the dry season, whereas shallow soils such as those on ridgetops can limit the amount of water available, regardless of magnitude of precipitation, as it will run off or recharge when the soil capacity is filled. These details are captured by the scale at which the climate is downscaled, and the hydrologic model is applied to the landscape. This application of CWD integrates the climate, energy loading, drainage, and available soil moisture to provide hydrologic response to changes in climate that reflect distinct landscapes and habitat characteristics.

\section{Results}

\section{Evaluation of downscaled climate parameters}

The comparison of downscaled climate parameters with measured station data at Hopland indicated that for all three climate parameters, the estimates of the parameters for this station using the downscaled 270-m data were closer to the measured monthly data for the 18 years of record at this station than the estimates using the 4-km PRISM data (Figure 3).

A look at all CIMIS and NWS stations in California shows a good correlation of estimated data from PRISM with measured data, especially for air temperature data (Figure 4). The regression of both $4-\mathrm{km}$ and $270-\mathrm{m}$ downscaled estimates with the measured data was not any different for all stations, with $r^{2}$ values remaining the same for precipitation and slightly improving for the 270-m estimates for air temperature. The slope, indicating the 1:1 fit to the measured data, was about the same for the 4- $\mathrm{km}$ and 270-m estimates of precipitation and minimum air temperature and was slightly less correlated for the maximum air temperature. All stations are represented for California in Figure 5, with colors indicating whether the 270-m estimate for maximum monthly air temperature was closer to or further from the measured data than the 4-km estimate. The yellow points indicate that the spatially downscaled estimate was within $0.1^{\circ} \mathrm{C}$ of the measured air temperature, which is equivalent to the reported instrument accuracy. There are no specific spatial trends although the larger deviations of the estimates from the measured data are shown more in the mountains than the valleys (Figure 5).

It is clear from Figure 1 that a fine scale of $270 \mathrm{~m}$ captures the topographic variability and corresponding ranges in air temperature, with a range in air temperature of $16.3^{\circ} \mathrm{C}$ to $44.9^{\circ} \mathrm{C}$ (standard deviation [SD] 6.1)

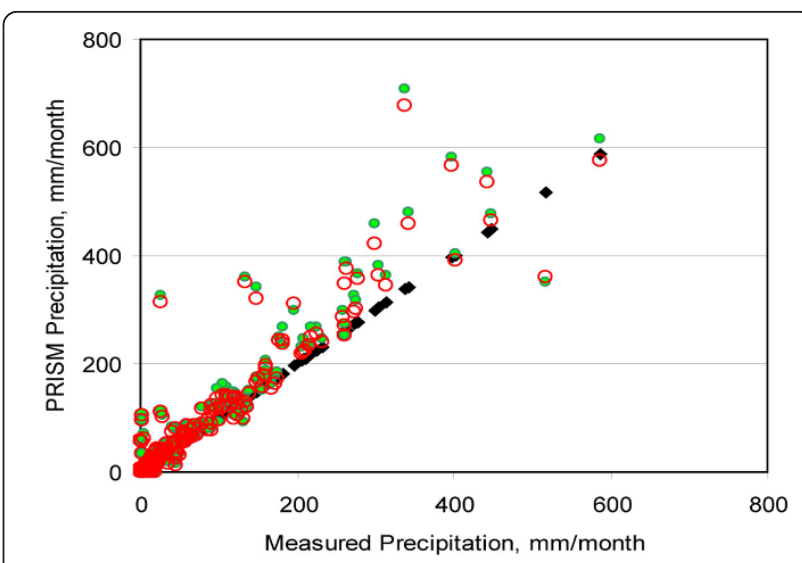

- CIMIS measured data • PRISM 4 km O PRISM Downscaled to 270 m
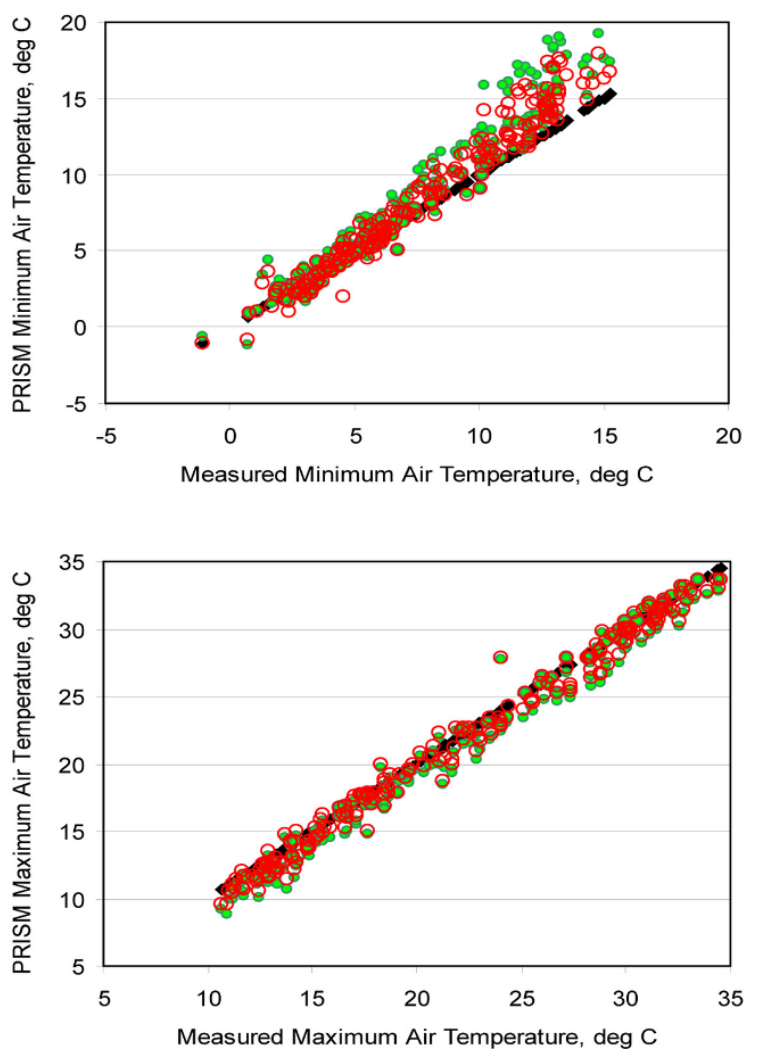

Figure 3 Downscaled climate parameters. Illustration of the fit between measured precipitation and minimum and maximum monthly air temperatures at the CIMIS station HOPLAND FS, the PRISM 4-km estimate, and the 270-m estimate that was spatially downscaled from the PRISM 4-km grid cell.

for June 2035 for the state of California at the12-km grid cell resolution, $15.3^{\circ} \mathrm{C}$ to $44.9^{\circ} \mathrm{C}$ (SD 6.0) for the $4-\mathrm{km}$ grid cell resolution, and $11.6^{\circ} \mathrm{C}$ to $47.0^{\circ} \mathrm{C}$ (SD 6.0) for the $270-\mathrm{m}$ grid cell resolution (Figure 1; Table $1)$. It is clear that as the spatial scale is reduced, the locations of the coldest temperatures that have the potential for offering refugia from warming are more 

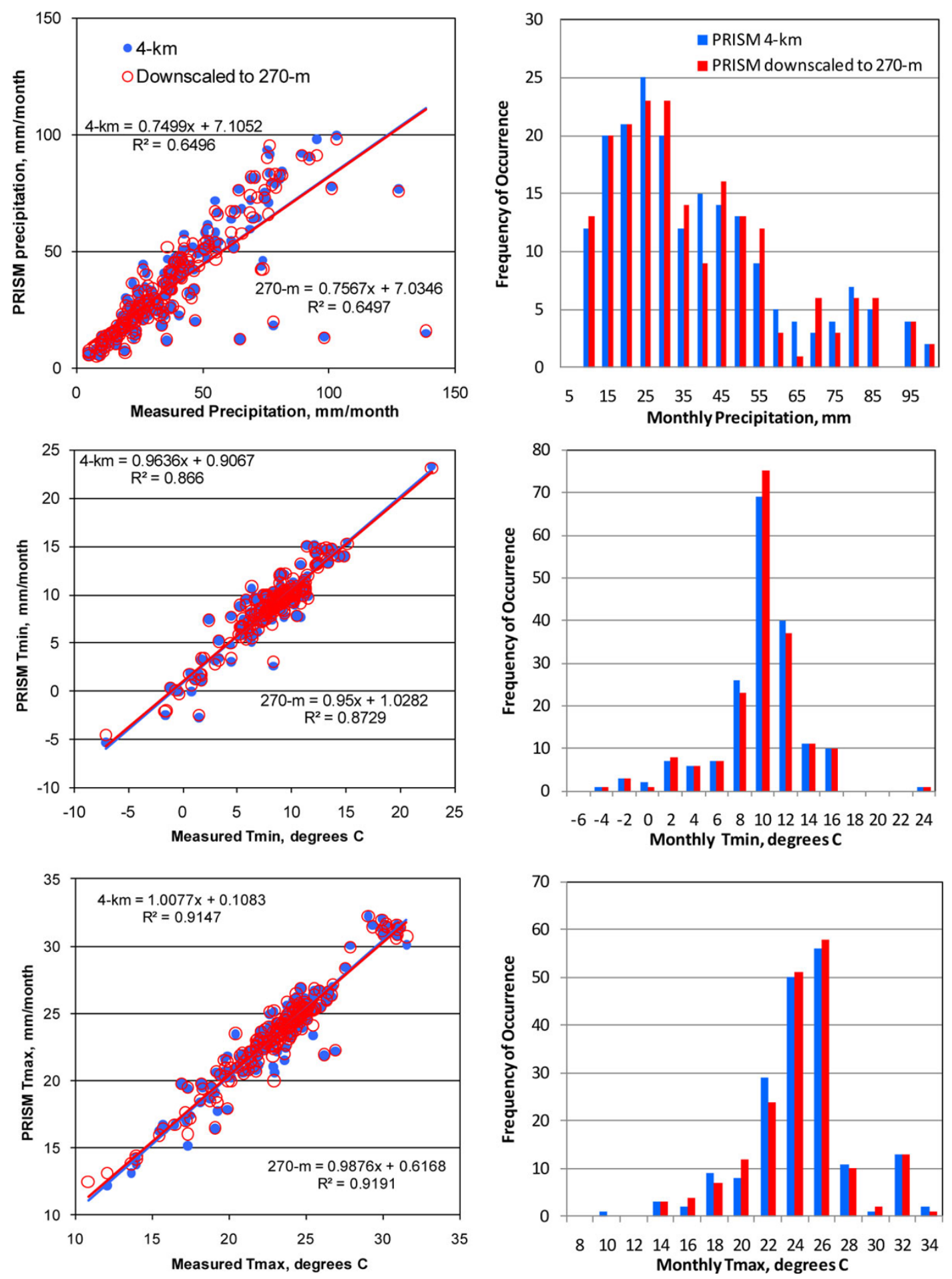

810121416182022242628303234 Monthly Tmax, degrees C

Figure 4 Comparisons of measured parameters. The measured parameters are compared with those developed from PRISM (Daly et al. 1994) at the $4-\mathrm{km}$ spatial resolution and spatially downscaled using modified gradient-inverse-distance-squared technique to $270 \mathrm{~m}$, and frequency histograms for 4-km and downscaled parameters. 


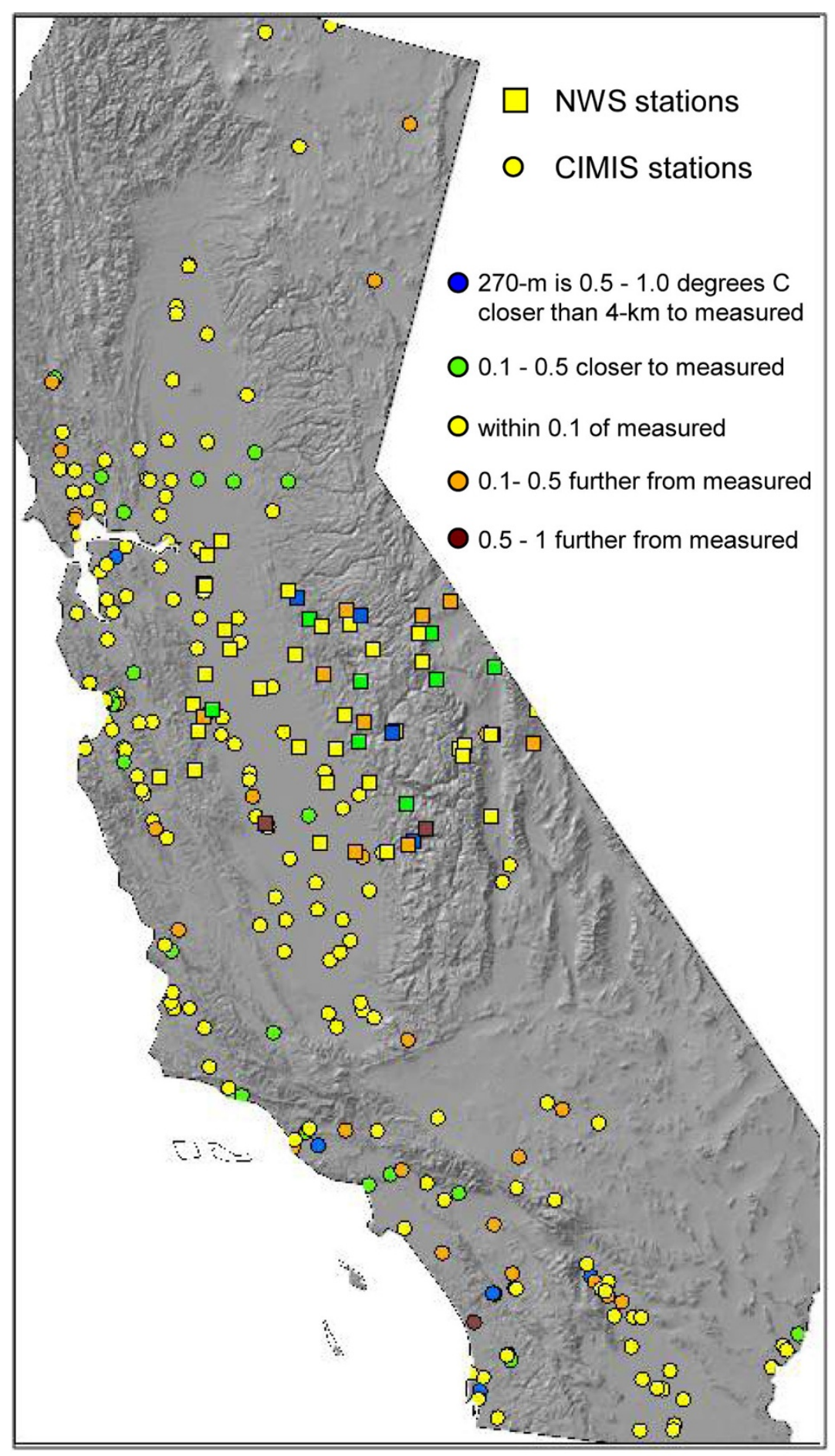

Figure 5 Location of CIMIS and NWS stations. The colour indicates if the PRISM 4-km estimate of maximum air temperature or the 270-m estimate that was spatially downscaled from the PRISM 4-km grid cell was closer to the measured data.

evident at both high elevations east of Owens Valley and low elevations in the Sierra Nevada, providing for information and enhanced interpretation for conservation planning.
Ecological application: fine-scale environmental refugia in the San Francisco North Bay area

Rising air temperatures over the twenty-first century are expected to force many vegetative species to either 


\begin{tabular}{lccccccc}
\hline Climate parameters & Measured & \multicolumn{2}{c}{ PRISM 4-km cells (Daly et al. } & \multicolumn{2}{c}{$\begin{array}{c}\text { PRISM cells downscaled to } \\
\text { 270 km }\end{array}$} & Number of stations \\
& Mean & Standard deviation & Mean & Standard deviation & Mean & Standard deviation & \\
\hline Precipitation (mm/month) & 38.1 & 23.8 & 35.8 & 22.4 & 35.7 & 22.2 & 195 \\
Minimum air temperature $\left({ }^{\circ} \mathrm{C}\right)$ & 8.2 & 3.5 & 8.8 & 3.7 & 8.8 & 3.6 & 183 \\
Maximum air temperature $\left({ }^{\circ} \mathrm{C}\right)$ & 23.2 & 3.5 & 23.5 & 3.7 & 23.5 & 3.6 & 185 \\
\hline
\end{tabular}

Means and standard deviations of measured climate parameters (from the National Weather Service and California Irrigation and Management Information System) and PRISM parameters for 4-km cells and cells downscaled to $270 \mathrm{~m}$ for cells occupied by climate stations.

migrate northward or up in elevation, or die off. A closer look at environmental conditions and stresses at a fine scale suggests that even at the end of the twentyfirst century, considering a medium-high emission scenario, fine-scale topographic or land surface features may provide refugia to maintain limited populations. For example, in the North Bay region of the San Francisco Bay area, the locations of tree species have been mapped for conservation planning (http://openspacecouncil.org). Three vegetation types serve as examples: Douglas-fir forest, redwood forest, and blue oak forest/ woodland. Historical climate data from PRISM (1971 to 2000), representing baseline conditions, and downscaled future projections for 2071 to 2100 were applied to the $\mathrm{BCM}$ that was used to simulate hydrologic conditions at the $270-\mathrm{m}$ scale.

The baseline CWD (1971 to 2000) is illustrated for basins in the North Bay (Figure 6a), indicating higher deficits in areas with shallower soils; soils with low water holding capacity; south-facing slopes; or further inland away from the direct coastal climatic influences. A closeup view of selected areas illustrates the differences in current CWD and future projections for 2071 to 2100 for three vegetation types. In Figure 6b, the mapped locations of Douglas-fir forest (at a 30-m scale) are indicated in red. For every 270-m cell in which Douglas-fir was mapped, the CWD was extracted to ascertain the range of conditions that could be considered suitable for Douglas-fir. The distribution ranged from 610 to $800 \mathrm{~mm} /$ year. Although Douglas-fir is currently restricted to the red areas, the current distribution of CWD within that range is shown in white indicating the area in which Douglas-fir could live if CWD was the only controlling factor. The future CWD distribution of the suitable range is in orange, and it illustrates the decline in potentially suitable habitat for Douglas-fir by the end of this century. When the red areas are overlain by the future CWD distribution, the mapped Douglas-fir areas decline as well, as noted by the blue cells. Of note is that the future Douglas-fir habitat is mostly on north-facing slopes and that the habitat is reduced by about $70 \%$.

The same analysis was done for a less abundant vegetation type, redwood forest (Figure 6c). Redwoods are found in areas of CWD with a slightly smaller range,
640 to $800 \mathrm{~mm} / \mathrm{yr}$. A close-up look at the future distribution of CWD indicates a large decline of area suitable for redwoods, with these areas on north-facing slopes and in the bottoms of valleys. Although suitable habitat declines and becomes less connected than the current distribution of mapped redwoods, there is ample suitable habitat in surrounding cells to provide nearby locations for preservation of the species. The final example is the blue oak forest/woodland (Figure 6d), which is located in areas with CWD of 710 to $900 \mathrm{~mm} / \mathrm{yr}$. This range of conditions declines only slightly over the next century, generally moving to areas of deeper soils. As the blue oak is currently at the edge of its range in the North Bay and probably already occupying selected areas of refuge, the suitable habitat of the mapped populations of blue oak does not decline significantly by the end of the next century, potentially providing an increase in the preferred habitats for this vegetation type.

To illustrate the variation in CWD among climate projections for grid cells mapped as redwood forest, all four climate scenarios are shown as cumulative probability distributions (Figure 7). These distributions represent the range of CWD in which the redwood forest currently lives and indicate that the lowest $10 \%$ of the population lives over a large range of low CWD, from 265 to $625 \mathrm{~mm} / \mathrm{yr}$, whereas the remaining 90\% lives in a smaller range of CWD. Those grid cells at very high CWD, such as the upper 10\%, live in locations that will experience increases in CWD in the future that exceed CWD currently defining the suitable habitat for redwood forest. All future climate projections indicate that CWD increases for all locations, increasing the least for the PCM models and the most for the GFDL models. The PCM A2 and GFDL B2 nearly overlie each other, except for very low CWD. The GFDL A2 scenario is more than twice the increase in CWD than the other three scenarios.

The distinction of fine-scale downscaling and hydrologic modeling is evident in an analysis comparing the mapped redwood forest shown in Figure 6c. The region around the figure is expanded to illustrate the CWD for the current and future climate (using GFDL A2 scenario) at the 270-m spatial resolution (Figure 8a) and 
(a)

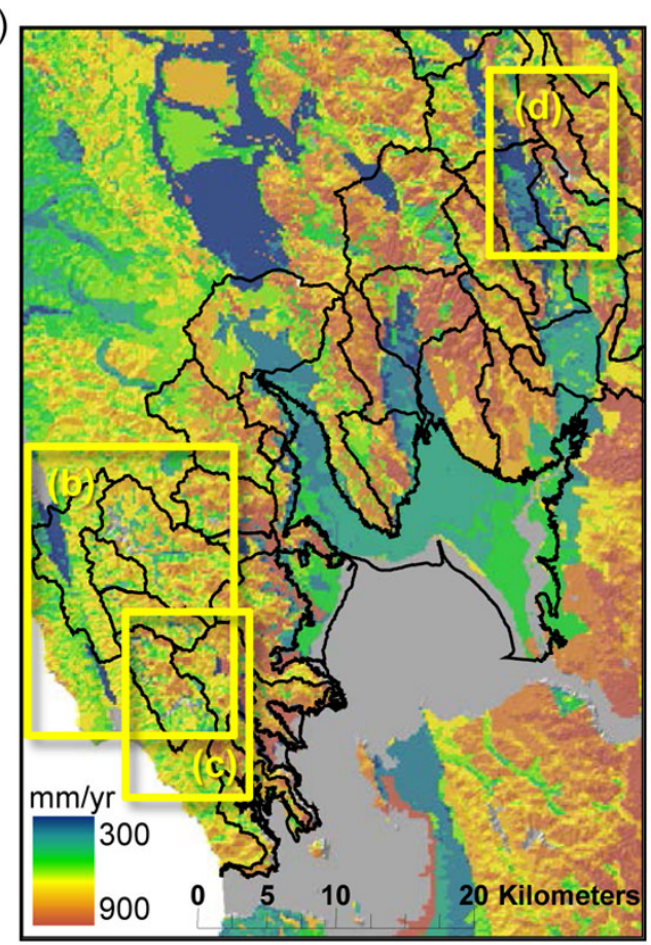

(c)

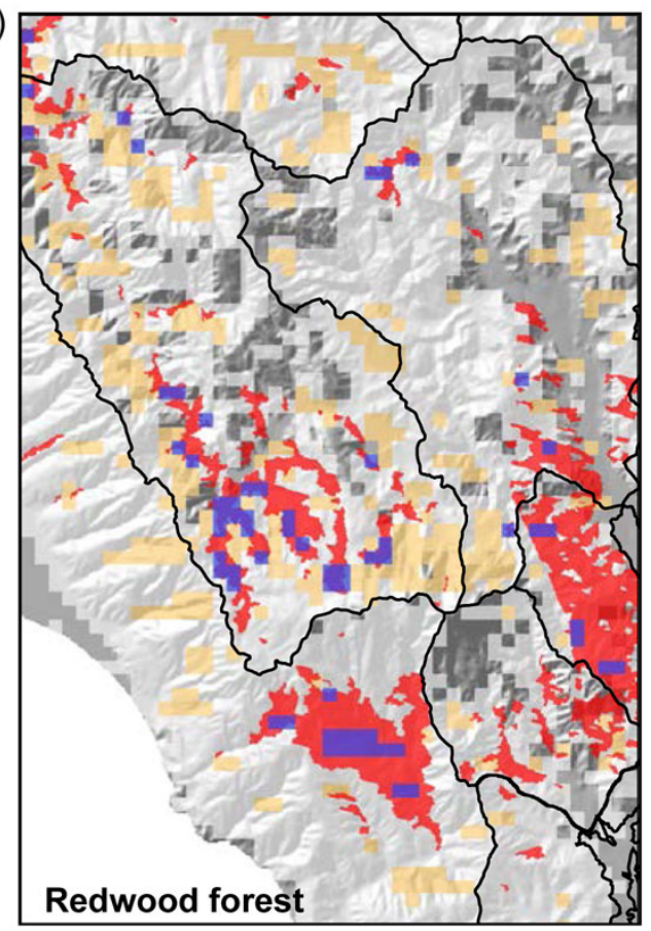

(b)

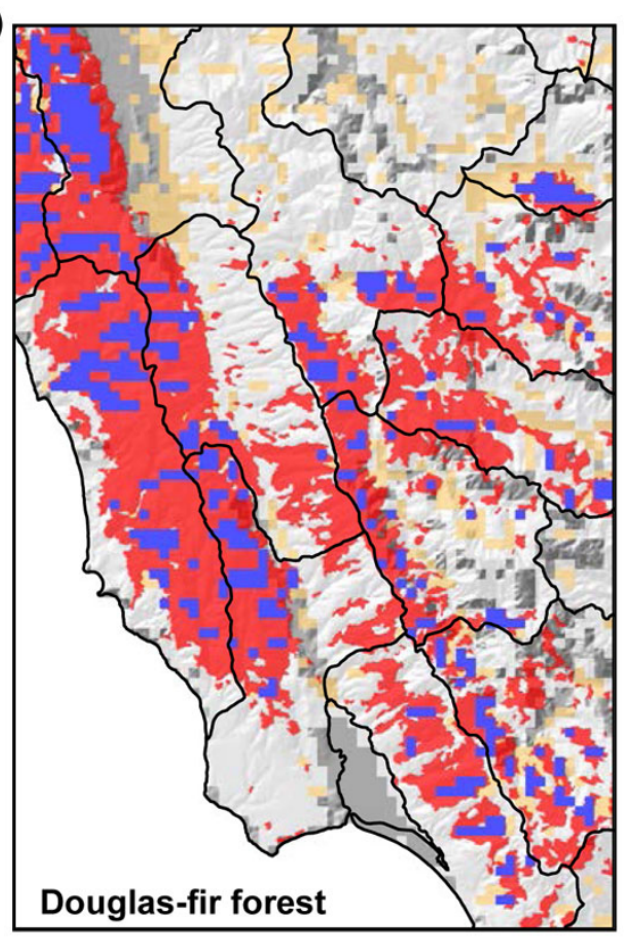

(d)

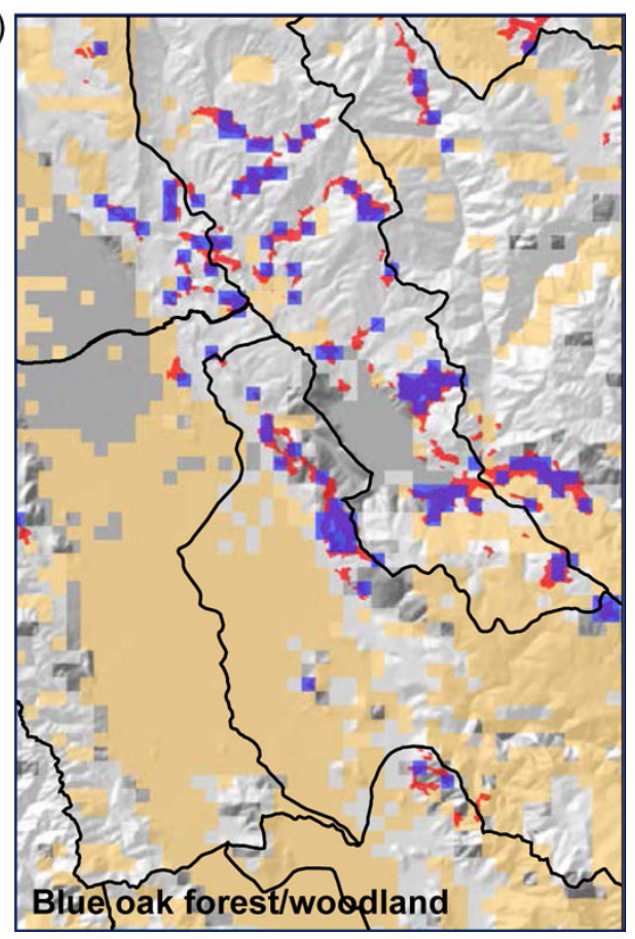

Figure 6 Climatic water deficit. CWD illustrated for (a) the San Francisco north bay area region and for three smaller areas (subset boxes in (a)) that indicate baseline (1971 to 2000) suitable CWD conditions (white), future (GFDL A2 2071 to 2100) suitable CWD conditions (orange), current mapped vegetation locations (red), and locations where future suitable CWD conditions overlap current mapped locations (blue) for (b) Douglasfir forest, (c) redwood forest, and (d) blue oak forest/woodland. 

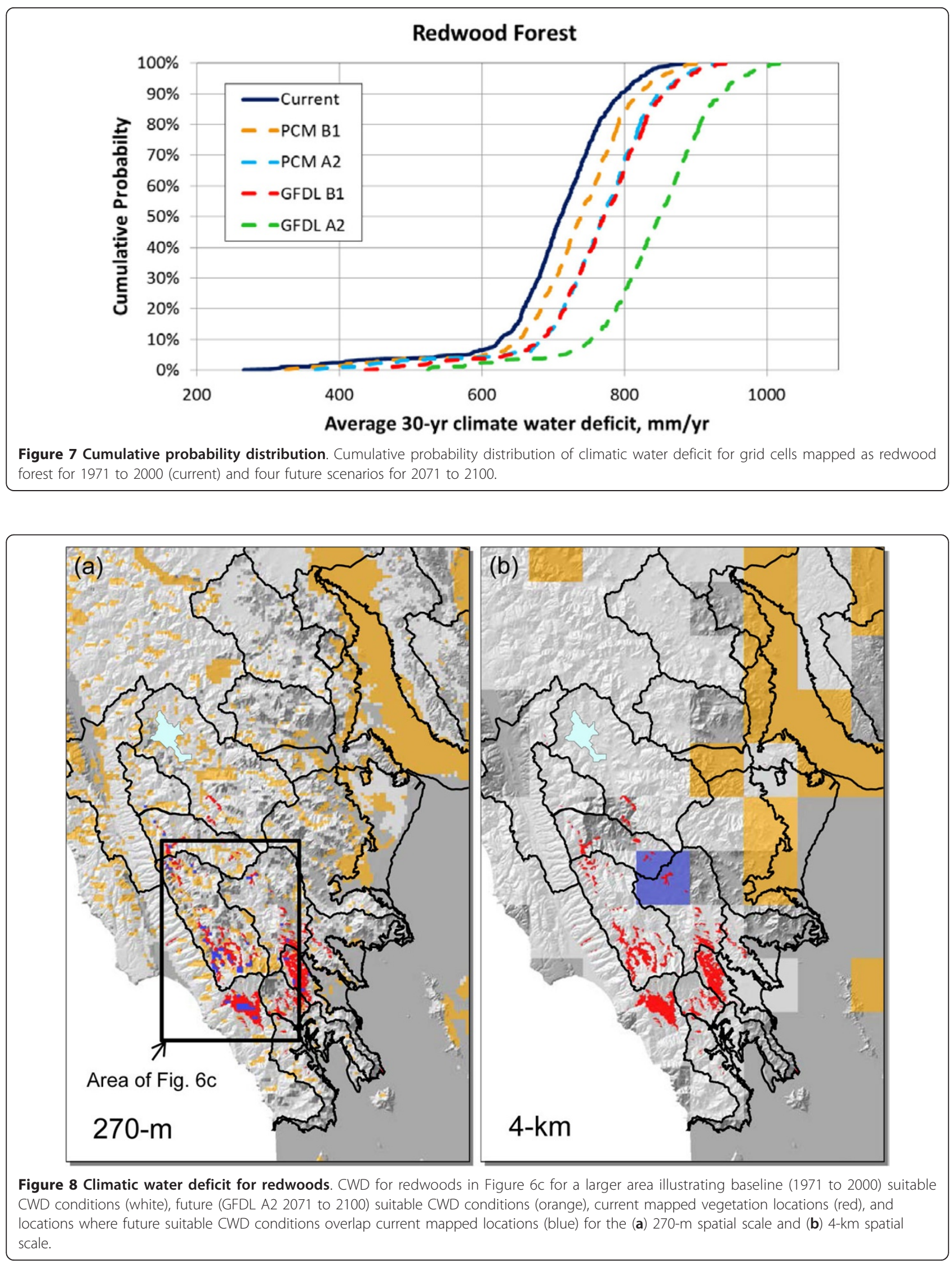
4-km spatial resolution (Figure $8 \mathrm{~b}$ ). At the fine scale, the suitable conditions in the future indicate locations on north-facing slopes and some valley bottoms, whereas at the coarse scale, the hydrologic response to climate represented by CWD does not indicate any topographically controlled conditions, with the exception of the large valley bottom in the upper right corner of Figure $8 b$.

The application of future climate projections to vegetation distributions and the potential change in environmental stressors are well served by the fine scale of the downscaled projections. The application of these projections in a fine-scale regional hydrologic model provides simulations of environmental conditions that occur at the hillslope scale that reflects energy-loading processes and changes in soil conditions that influence the presence and distribution of vegetation types.

\section{Conclusions}

Climate change projections available as output from global climate models require downscaling to scales that appropriately reflect the environmental processes under consideration. Depending on the process of concern, this downscaling may range from spatial extents of kilometers to meters. As projections maintain their own set of uncertainties on the basis of the assumptions chosen for global climate modeling and greenhouse gas emission scenarios, it is advisable to incur the least additional uncertainty attributable to the downscaling scheme itself. The approaches chosen here reflect high rigor and defensible error for the spatial downscaling method and the statistical downscaling method upon which it relies. The constructed analogue method (Hidalgo et al. 2008) skillfully reproduces monthly variations of precipitation and average temperature anomalies, as well as seasonal cycles, across the contiguous United States. The modified gradient-inverse-distancesquared spatial downscaling technique described here does not introduce additional uncertainty in the downscaling process and may indeed improve the estimate of the climate parameter by incorporating the deterministic influence (such as lapse rates or rain shadows) of location and elevation on climate.

The fine-scale downscaling illustrated provides an enhancement to the suite of options for environmental analysis when climate projections are translated into hydrologic and environmental impacts via hydrologic modeling. Analyses may include regional to site-specific applications such as regional vegetation distributions, basin-scale water availability studies, or water deficits on north- or south-facing hillslopes. These details are captured by the scale at which the climate is downscaled and the hydrologic model is applied to the landscape. The representation of topoclimates and hydrologic response to climate at fine scales can provide impacts at the scale that the organism experiences and may indicate potential refugia as climates warm to guide land and resource management. The application of CWD integrates the climate, energy loading, drainage, and available soil moisture to provide hydrologic response to changes in climate that reflect distinct landscapes and habitat characteristics. Environmental impacts as a result of changing climate will be evident at multiple scales and thus require the tools to perform analyses at the same scales reflecting the changing processes.

\section{Acknowledgements}

The authors would like to acknowledge Michael Dettinger (USGS/Scripps) for his cooperation in facilitating the further spatial downscaling of several climate scenarios, and both Michael and Randall Hanson (USGS) for providing rigorous and extremely useful reviews of this manuscript. Four additional anonymous reviewers provided excellent reviews that improved the quality and relevance of the research as represented by this manuscript.

\section{Authors' contributions}

AF developed the methodology, did the downscaling, and drafted the 'Methods: downscaling approach and application' section of the manuscript. LF did the analyses, provided the applications of the methods, and drafted the manuscript and figures. All authors read and approved the final manuscript.

\section{Competing interests}

The authors declare that they have no competing interests.

Received: 26 July 2011 Accepted: 10 February 2012

Published: 10 February 2012

\section{References}

Ackerly DD, Loarie SR, Cornwell WK, Weiss SB, Hamilton H, Branciforte R, Kraft NJB (2010) The geography of climate change: implications for conservation biogeography. Diversity and Distributions, 16(3): pp 476-487

Ashcroft MB, Chishold LA, French KO (2008) The effect of exposure on landscape scale soil surface temperatures and species distribution models. Landscape Ecol 23:211-225

Bouwer LM, Aerts JC, Van de Coterlet GM, Van de Giesen N, Gieske A, Mannaerts C (2004) Evaluating downscaling methods for preparing global circulation model (GCM) data for hydrological impact modeling. Climate change in contrasting river basins. CAB International Publishing, London pp 25-47

California Department of Water Resources (2008) Managing an uncertain future: climate change adaptation strategies for California's water. White Paper for State of California

Callaway RM, Davis FW (1998) Recruitment of Quercus agrifolia in central California: the importance of shrub-dominated patches. J Vegetation Science 9:647-656

Cayan DR, Maurer EP, Dettinger MD, Tyree M, Hayhoe K (2008) Climate change scenarios for the California region. Climatic Change 87(Suppl 1):S21-S42

Daly C, Neilson RP, Phillips DL (1994) A statistical-topographic model for mapping climatological precipitation over mountainous terrain. J Appl Meteor 33:140-158

Davis FW, Borchert M, Meentemeyer RL, Flint AL, Rizzo DM (2010) Pre-impact forest composition and ongoing tree mortality associated with sudden oak death in the Big Sur region, California. For Ecol Manage 259:2342-2354

Delworth T., et al (2006) GFDL's CM2 global coupled climate models - Part 1: formulation and simulation characteristics. J Climate 19(5):643-674

Dobrowski SZ (2010) A climatic basis for microrefugia: the influence of terrain on climate. Global Change Biology. doi:10.1111/j.1365-2486.2010.02263.x

Flint AL, Flint LE, Hevesi JA, Blainey JM (2004) Fundamental concepts of recharge in the Desert Southwest: a regional modeling perspective. In: Hogan JF, 
Phillips FM, Scanlon BR (ed) Groundwater recharge in a desert environment: the southwestern United States. Water science and application, vol 9. American Geophysical Union, Washington, D.C, pp 159-184

Flint LE, Flint AL (2007) Regional analysis of ground-water recharge. Groundwater recharge in the arid and semiarid southwestern United States. US Geol Surv Prof Paper 1703 pp 29-59

Geiger R, Aron RH, Todhunterer P (2003) The climate near the ground. Rowman and Littlefield, Lanham, 6

Guisan A, Thuiller W (2005) Predicting species distribution: offering more than simple habitat models. Ecol Lett 8:993-1009

Gurdak JJ, Hanson RT, Green RT (2009) Effects of climate variability and change on groundwater resources of the United States. US Geol Surv Fact Sheet 2009-3074:4

Hanson RT, Dettinger MD (2005) Ground-water/surface-water responses to global climate simulations, Santa Clara-Calleguas Basin, Ventura County, California, 1950-93. J Amer Wat Res Assoc 43(3):517-536

Hellman JJ, Weiss SB, McLaughlin JF, Ehrlich PR, Murphy DD, Launer AE (2004) Structure and dynamics of Edith's Checkerspot population. On the wings of Checkerspots: a model system for population biology. Oxford University Press, Oxford pp 34-62

Hidalgo HG, Dettinger MD, Cayan DR (2008) Downscaling with constructed analogues: daily precipitation and temperature fields over the United States. Calif Energy Comm PIER Energy-Related Environ Res. CEC-500-2007-123

IPCC (2007) IPCC fourth assessment report. Climate change 2007: Projections of future changes in climate. In: Solomon S, Qin D, Manning M, Chen Z, Marquis M, Averyt KB, Tignor M, Miller HL (ed) Working group I intergovernmental panel on climate change. Cambridge Univ Press, Cambridge

Keyes CR, Maguire DA, Tappeiner JC (2009) Recruitment of ponderosa pine seedlings in the Cascade Range. Forest Ecol Manag 257:495-501

Loarie SR, Duffy PB, Hamilton H, Asner GP, Field CB, Ackerly DD (2009) The velocity of climate change. Nature 462:1052-1055

Lookingbill TR, Urban DI (2003) Spatial estimation of air temperature differences for landscape-scale studies in montane environments. Agric For Meterolo 114:141-151

Lookingbill TR, Urban DI (2005) Gradient analysis, the next generation: towards more plant-relevant explanatory variables. Can J For Res 35:1744-1753

Lundquist JD, Flint AL (2006) Onset of snowmelt and streamflow in 2004 in the western United States: how shading may affect spring streamflow timing in a warmer world. J Hydrometeor 7:1199-1217

Maurer EP, Hidalgo HG (2008) Utility of daily vs. monthly large-scale climate data: an intercomparison of two statistical downscaling methods. Hydrol Earth Syst Sci 12:551-563

Meehl GA, Washington WM, Wigley TML, Arblaster JM, Dai A (2003) Solar and greenhouse gas forcing and climate response in the twentieth century. J Climate 16(3):426-444

Milly PCD, Betancourt J, Falkenmark M, Hirsch RM, Kundzewicz ZW, Lettenmaier DP, Stouffer RJ (2008) Stationarity is dead: whither water management. Science 319:573-574. doi:10.1126/science.1151915

Nalder IA, Wein RW (1998) Spatial interpolation of climatic normals: test of a new method in the Canadian boreal forest. Agric Forest Meteor 92:211-225

Nakic'enovic' N, Alcamo J, Davis G, de Vries B, Fenhann J, Gaffin S, Gregory K, Grubler A, Jung TY, Kram T (2000) Intergovernmental panel on climate change special report on emissions scenarios. Cambridge Univ Press, Cambridge

Peterson DL, Schreiner EG, Buckingham NM (1998) Gradients, vegetation and climate: spatial and temporal dynamics in the Olympic Mountains, U.S.A. Global Ecology and Biogeography Letters 6(1):7-17

Randin CF, Engler R, Normand S, Zappa M, Zimmermann NE, Pearman PB, Vittoz P, Thuiller W, Guisan A (2009) Climate change and plant distribution: local models predict high elevation persistence. Global Change Biol 15:1557-1569

Scherrer D, Korner C (2010) Topographically controlled thermal-habitat differentiation buffers alpine plant diversity against climate warming. J Biogeography 38:406-416

Sork VL, Davis FW, Westfall R, Flint AL, Ikegami M, Wang H, Grivet D (2010) Gene movement and genetic association with regional climate gradients in California valley oak (Quercus lobata Nee). Molec Ecol 19(17):3806-3823

Stephenson NL (1998) Actual evapotranspiration and deficit: biologically meaningful correlates of vegetation distribution across spatial scales. J Biogeog 25(5):855-870
Stouffer ., et al (2006) GFDL's CM2 global coupled climate models - Part 4: idealized climate response. J Climate 19:723-740

Trivedi MR, Berry PM, Morecroft MD, Dawson TP (2008) Spatial scale affects bioclimate model projections of climate change impacts on mountain plants. Global Change Biol 14:1089-1103

van den Dool H, Huang J, Fan Y (2003) Performance and analysis of the constructed analogue method applied to US soil moisture over 1981-2001. J Geophys Res 108(D16)

Washington WM, Weatherly JW, Meehl GA., et al (2000) Parallel climate model (PCM) control and transient simulations. Climate Dyn 16:755-774

Weiss SB, Weiss AD (1998) Landscape-level phenology of a threatened butterfly: a GIS-based modeling approach. Ecosystems 1:299-309

Wood AW, Leung LR, Sridhar V., et al (2004) Hydrologic implications of dynamical and statistical approaches to downscaling climate model outputs. Climatic Change 62:189-216

Wiens JA (1989) Spatial scaling in ecology. Funct Ecol 3:385-397

doi:10.1186/2192-1709-1-2

Cite this article as: Flint and Flint: Downscaling future climate scenarios to fine scales for hydrologic and ecological modeling and analysis. Ecological Processes 2012 1:2.

\section{Submit your manuscript to a SpringerOpen ${ }^{\mathcal{O}}$ journal and benefit from:}

- Convenient online submission

- Rigorous peer review

- Immediate publication on acceptance

- Open access: articles freely available online

- High visibility within the field

- Retaining the copyright to your article

Submit your next manuscript at $\boldsymbol{~ s p r i n g e r o p e n . c o m ~}$ 